\title{
STRATEGI PENINGKATAN MUTU PELAYANAN DI RUMAH SAKIT UMUM PADANGSIDIMPUAN
}

\author{
Ja'far Nasution \\ Institut Agama Islam Negeri Padangsidimpuan \\ Jalan T. Rizal Nurdin Km. 4,5 Sihitang, Padangsidimpuan \\ Email : ucoknas@yahoo.co.id
}

\begin{abstract}
Abstrak,
Pelayanan yang terjadi di Rumah sakit umum Padangsidimpuan kurang sempurna dan yang menjadi rumusan masalah ialah bagaimana strategi peningkatan pelayanan di Rumah Sakit Umum Daerah Padangsidimpuan dan bagaimana strategi peningkatan mutu pelayanan di RSUD Padangsidimpuan. Tujuan penelitian ini untuk mengetahui alasan masyarakat berminat terhadap RSUD Padangsidimpuan dan untuk mengetahui startegi peningkatan pelayanan RSUD Padangsidimpuan. Strategi dan pelayanan merupakan bagian dari manajemen. Lokasi dan waktu penelitian yang dilakukan yaitu di Rumah Sakit Umum Daerah Padangsidimpuan Sumatera Utara yang berada di Jl. Dr. FI Tobing No.2. Jenis penelitian yang digunakan yaitu penelitian dengan analisis data kualitaif dengan sumber data primer wawancara. Penelitian ini menggunakan analisis Eksternal dan Internal, SWOT dan Matriks SWOT. Berdasarkan hasil penelitian yang dilakukan dapat diketahui bahwa strategi SO yakni adanya dorongan dari pemerintah dalam melengkapi fasilitas-fasilitas medis yang belum pernah ada dalam menangani masalah pasien. Strategi WO yakni bantuan dari pemerintah dan manajer puncak sangat membantu membuat team khusus dalam menangani masalah kebersihan yang ada. Strategi ST Rumah Sakit negeri masih diminati masyarakat Tapanuli Bagian Selatan. Adapun strategi WT adalah melakukan peningkatan pelayanan yang memuaskan pasien dan keluarga.
\end{abstract}

Kata Kunci: Strategi, Matriks SWOT, Mutu Pelayanan

\begin{abstract}
,
In the case of services that occur in Padangsidimpuan Public Hospital is less than perfect and the problem formulation is how to improve service strategies at Padangsidimpuan Regional General Hospital and how to improve services in Padangsidimpuan Hospital. The use of visualization is not unusual for the author, but as a means of alternative strategies that aim to develop scientific knowledge for people who are interested in reading or enforcing references from this paper. The discussion of this paper deals with business management, this paper deals with how service strategies in satisfying patients in hospitals. Strategy and service are part of management. The location and time of the research were carried out at the Regional General Hospital at the North Sumatra. This research was conducted in August 2018. The type of research used was research with qualitative data analysis with primary data source interviews. This study uses external and internal analysis, SWOT and SWOT Matrix. Based on the results of research conducted by the researcher, it can be seen that the SO strategy is an encouragement from the government in completing medical facilities that have never existed in dealing with patient problems. WO's strategy of assistance from the government and top managers greatly helped to create a special team in handling existing hygiene problems. ST strategy, state hospitals are still in demand by the South Tapanuli community. There are WT strategy to improve services that will satisfy patients and families.
\end{abstract}

Keywords: Strategy, Strengths, Weaknesses, Opportunities, Threats and service quality 


\section{PENDAHULUAN}

Perusahaan sebagai sebuah organisasi yang menghasilkan produk atau jasa sangat membutuhkan sumber daya bagi kegiatan operasinya. Sumber daya yang dibutuhkan itu terdiri dari sumber daya fisik (man, money, method, market, machine,material) dan sumber daya konseptual (informasi / data). Manusia sebagai salah satu sumberdaya insani berperan dalam menentukan semua kegiatan yang ada di perusahaan yang tercermin melalui kinerja karyawan. Kinerja merupakan sesuatu yang sangat kompleks dan senantiasa perlu ditingkatkanbaik dari sisi individu, kelompok maupun organisasi.

Suatu organisasi atau instansicenderung memilih karyawan yang merniliki pengalaman kerja yang banyak, atau dengankata lain yang memiliki masa kerja yang cukup pada bidang kerja yang sama atau sejenisdengan apa yang akan ditugaskan nantinyaMenurut Simamora "Deskripsi dari kinerja menyangkut tiga komponen penting, yaitu tujuan yang akan memberikan arah dan mempengaruhi bagaimana seharusnya perilaku kerja yang diharapkan organisasi terhadap setiap personel.” Kedua adalah ukuran, dibutuhkan untuk mengetahui apakah seorang personel telah mencapai kinerja yang diharapkan, untuk itu kuantitatif dan kualitatif standar kinerja untuk setiap tugas dan jabatan personal memegang peranan penting. Ketiga, penilaian kinerja reguler, yang dikaitkan dengan proses pencapaian tujuan kinerja setiap personel. Tindakan ini akan membuat personel untuk senantiasa berorientasi terhadap tujuan dan berperilaku kerja sesuai dan searah dengan tujuan yang hendak dicapai.

Kinerja memiliki arti suatu hasil kerja yang dapat dicapai oleh seseorang atau sekelompok orang dalam suatu organisasi sesuai dengan wewenang dan tanggung jawab masing-masing. dalam rangka mencapai tujuan organisasi secara legal, tidak melanggar hukum dan sesuai dengan moral maupun etika kinerja pada dasarnya adalah apa yang dilakukan atau tidak dilakukan karyawan sehingga mempengaruhi seberapa banyak mereka memberi kontribusi kepada instansi atau organisasi termasuk pelayanan kualitas yang disajikan, Menurut Mathis dan Jackson "Insentif memiliki keterkaitan dengan kinerja karyawan." Menurut Hasibuan "Mengemukakan bahwa Insentif adalah tambahan balas jasa yang diberikan kepada karyawan tertentu yang prestasinya di atas prestasi standar." Insentif ini merupakan alat yang dipergunakan pendukung prinsip adil dalam pemberian kompensasi. Selain itu menurut Mangkunegara "Mengemukakan bahwa Insentif adalah suatu bentuk motivasi yang dinyatakan dalam bentuk uang atas dasar kinerja yang tinggi dan juga merupakan rasa pengakuan dari pihak organisasi terhadap kinerja karyawan dan kontribusi terhadap organisasi." Berdasarkan uraian diatas jelaslah bahwa kinerja karyawan dipengaruhi oleh insentif (Gani,2018).

Tantangan utama manajemen saat ini berkisar pada menciptakan organisasi yang lebih baik, yaitu organisasi yang mampu menjamin kelangsungan eksistensinya, siap menghadapi berbagai tantangan, mampu menghilangkan berbagai kendala serta memanfaatkan berbagai 
peluang yang timbul. Berbagai tantangan dimasa depan itu antara lain, globalisasi ekonomi,, perubahan geopolitik, pengangguran, peningkatan taraf hidup, keaneka ragaman tenaga kerja, perkembangan teknologi, masalah demografi, kemudian timbulnya berbagai kejutan yang tidak diperkirakan sebelumnya, hingga kini banyak penelitian dan kasus, dapat disimpukan bahwa teori manajemen modern masih gagal dalam mengatur perilaku individu menuju organisasi yang baik. Pengelolaan perusahaan yang berorientasi Islam memerlukan pendekatan duniawi maupun ukhrawi sekaligus. Artinya setiapperusahaan antusias untuk melakukan hal tersebut, pastinya setiap strategi yang ada dalam perusahaan tersebut akan terkelola dengan baik, apabila hal duniawi dan ukhrowinya seimbang (Usman, 2015).

Pembangunan kesehatan merupakan bagian integral dari pembangunan nasional. Jasa pelayanan kesehatan salah satu kebutuhan yang penting, seiring dengan meningkatnya kesadaran masyarakat terhadap pentingnya arti kesehatan.

Salah satu lembaga yang menangani masalah pelayanan kesehatan adalah lembaga berbentuk rumah sakit. Rumah sakit secara khusus merupakan suatu lembaga yang menangani masalah kesehatan yang bersifat non profit oriented. Selain itu rumah sakit tidak membatasi jumlah pasien yang dilayani, sesuai dengan tujuannnya untuk memberikan pelayanan kepada masyarakat. Masyarakat masih memandang bahwa pelayanan kesehatan dari rumah sakit sebagai suatu pelayaanan jasa yang bersifat social. Sehingga tidak etis untuk menerapkan prinsip profit maximation dalam industry pelayanan kesehatan. Rumah sakit sesuai dengan sifatnya, tidak bertujuan mencari laba, tapi bukan berarti rumahsakit mencari laba dalam operasinya. Semenjak otonomi daerah fungsi rumah sakit mengalami pergeseran yakni dari fungsi social menjadi fungsi ekonomi. Menurut Laksono mengatakan bahwa” Keberadaan rumah sakit sebagai fungsi social yang non profit, pada akhirnya abad sekarang telah berubah menjadi fungsi kearah ekonomi ( Henri, 2010).

Rumah sakit Umum Padangsidimpuan merupakan rumah sakit kelas C dan merupakan salah satu instansi pemerintah berstatus negeri, rumah sakit ini banyak menyediakan layanan diantaranya: Pelayanan administrasi dan manajemen, pelayananpelayan medis dan pelayanan-pelayanan penunjang non medis.

Rumah Sakit Umum Daerah Padangsidimpuan ini dikenal oleh masyarakat tapanuli bagian Selatan akan tetapi terdapat berbagai keluhan dari masyarakat terkat pelayanan yang disediakan diantaranya kurangnya dokter-dokter yang ahli atau spesialis untuk menangani masalah pasien, kurangnya pasokan air bersih, kebersihan lokasi tidak begitu diperhatikan, kurangnya fasilitas yang diberikan rumah sakit sehingga bayak sekali komplain atau keluhan dari pasien atau masyarakat ketika menginap maupun berkunjung kerumah sakit itu. Berdasarkan masalah-masalah diatas maka dapat dirumuskan masalah dalam penelitian ini adalah Apa saja Faktor internal dan factor eksternal yang menyebabkan mayasrakat berminat 
terhadap pelayanan Rumah sakit Umum daerah padangsidimpuan dan bagaimana strategi pengembangan pelayanan dirumah sakit ini? Adapun tujuan penelitian ini adalah untuk mengetahui apa yang menjadi penyebabnya masyarakat berminat kepada pelayanan Rumah Sakit Umum daerah padangsidimpuan dan untuk mengetahui strategi pengembangan pelayanan Rumah Sakit Umum Daerah Padangsidimpuan.

Penelitian ini menjadi sumber referensi dan mengamati sejauh mana perkembangan pelayanan di Rumah Sakit Umum daerah padangsidimpuan dan merupakan sebuah edukasi penambah wawasan kepada masyarakat tentang pelayanan-pelayanan yang ada pada rumahsakit tersebut. Berdasarkan penjelasan diatas maka sebagai putra daerah Tapanuli Bagian Selatan tertarik untuk melakukan penelitian dengan judul:" Strategi Peningkatan

\section{Mutu Pelayanan di Rumah Sakit Umum Padangsidimpuan”.}

\section{TINJAUAN TEORITIK.}

Bagi organisasi bisnis, starategi dimaksudkan untuk mempertahankan keberlangsungan bisnis perusahaan dibandingkan para pesaingnya dalam memenuhi konsumen. Stratege pada level perusahaan dilakukan perusahaan sehubungan dengan persaingan antara perusahaan dalam sector bisnis dijalankannya secara keseluruhan. Fred R. David menjelaskan bahwa "Proses manajemen strategis terdiri dari tiga tahapan, yaitu: Memformulasikan strategi, mengimplementasikan strategi dan meng evaluasi strategi” (David, 2009).

Strategi berasal dari bahasa Yunani "Strategas" (stratos: militer, $A g$ : memimpin) yang berarti generalship atau sesuatu yang dikerjakan para jenderal perang dalam membuat rencana untuk memenangkan perang. Konsep ini relevan pada zaman dahulu yang sering diwarnai oleh perang dimana jenderal dibutuhkan untuk memimpin angkatan perang. Secara umum, Strategi merupakan cara atau proses yang digunakan untuk tercapainya sebuah tujuan. Strategi merupakan tindakan yang bersifat incremental (senantiasa meningkat) dan terus menerus, yang dilakukan berdasarkan sudut pandang tentang tujuan yang diharapkan.

Menurut Johnson and Scholes, Strategi adalah arah dan ruang lingkup sebuah organisasi dalam jangka panjang yang mencapai keuntungan bagi organisasi melalui konfigurasi sumber daya dalam lingkungan yang menantang, untuk memenuhi kebutuhan pasar dan memenuhi harapan pemangku kepentingan. Menurut Ismail “ Prima, peningkatan dan pemantapan sistem manajemen pelayanan publik menuju pelayanan prima menekankan pada fokus perhatian yang dapat dilakukan melalui penyiapan sumber daya aparatur yang sadar akan fungsinya sebagai pelayan masyarakat.”Sedangkan Sedarmayanti “ menyatakan pelayanan prima adalah pelayanan yang diberikan kepada pelanggan (masyarakat) minimal sesuai dengan standar pelayanan (cepat, tepat, akurat, murah, ramah).”Tujuan dari pelayanan prima menurutIsmail adalah memberikan kepuasan atau sesuai dengan keinginan pelanggan. 
Oleh karena itu, mutu pelayanan publik adalah kesesuaian antara harapan dan keinginan dengan kenyataan dari praktik pelayanan yang diberikan oleh organisasi publik (Wulan dan Mosam).

Tahapan formulasi strategi ditujukan untuk menghasilkan strategi-strategi induk dan umum ditingkat korporasi dengan arahan nilai utama dan orientasi strategi perusahaan serta turunan berikutnya. Diatas strategi korporasi, sebenarnya terdapat nilai-nilai utama yang memandu arah organisasi, disebut nilai utama, sebab ia menjadi sandaran utama yang akan memayungi semua aktivitas organisasi. Karena dalam perspektif islam keberadaan manajemen perusahaan dipandang pula sebagai suatu sarana untuk memudahkan implementasi islam dalam kegiatan bisnis perusahaan tersebut, maka nilai-nilai islam inilah yang sesungguhnya nilai utama organisasi yang menjadi paying strategi hingga taktis seluruh aktivitas perusahaan. Nilai-nilai Islam ini pula yang membuat orientasi strategi perusahaan tidak melulu mengejar keuntungan duniawi saja sertai abai pada pencapaian keberkahan Allah SWT (Sai'd , 2003).

Peningkatan merupakan fungsi operasional kedua dari manajemen personalia. Pengembangan karyawan perlu dilakukan secara terencana dan berkesinambungan. Agar pengembangan dapat dilakukan dengan baik, harus lebih dahulu ditetapkan suatu program pengembangan karyawan. Program pengembangan karyawan hendaknya disusun secara cermat didasarkan kepada metode-metode ilmiyah serta berpedoman kepada keterampilan yang dibutuhkan perusahaan saat ini maupun masa depan. Pengembangan harus bertujuan untuk meningkatkan kemampuan teknis, teoritis, konseptual, dan moral karyawan supaya prestasi kerjanya baik dan mencapai hasil yang optimal. (Hasan, 2010) menyatakan bahwa pengembangan sumber daya manusia merupakan langkah kelanjutan dari proses penyediaan tenaga kerja, yang pada dasarnya bertujuan untuk memastikan dan memelihara tenaga kerja yang tersedia tetap memenuhi kualifikasi yang diperyaratkan sehingga selaras dengan perencanaan strategi perusahaan serta tujuan perusahaan dapat tercapai sebagaimana yang direncanakan (Sule dan Saefullah, 2000).

Pelayanan adalah setiap tindakan atau kegiatan yang dapat ditawarkan oleh suatu pihak kepada pihak lain, yang pada dasarnya tidak berwujud dan tidak mengakibatkan kepemilikan apapun. Pelayanan merupakan syarat utama bagi kelangsungan hidup suatu bank, khususnya bank syariah. Pelayanan yang baik serta kenyamanan yang diberikan kepada nasabah dapat menentukan laju pertumbuhan suatu bank.

Kualitas pelayanan merupakan kemampuan merencanakan, menciptakan, dan menyerahkan produk yang bermanfaat luar biasa bagi nasabah. Kualitas pelayanan karyawan sebagai jaminan atas ketersediaan produk, rasa responsivitas, biaya administrasi yang hemat, ketetapan waktu memberikan pelayanan dan waktu tunggu yang lebih pendek, kesempurnan 
pelayanan, serta kemampuan menimbulkan kesenangan dan perasaan nyaman pada pelanggan.

Dalam memberikan pelayanan, setidaknya bank harus memenuhi 5 kriteria kualitas pelayanan yang berkualitas, sehingga diharapkan dapat menciptakan kepuasan pasien yaitu

Pertama Reliability (keandalan), yaitu kemampuan untuk memberikan pelayanan yang sesuai dengan janji yang ditawarkan. Pelayanan akan dapat dikatakan reliabel apabila dalam perjanjian yang telah diungkapkan dicapai secara akurat

Kedua Responsiveness (daya tanggap) yaitu respon atau kesigapan karyawan dalam membantu pelanggan dan memberikan pelayanan yang cepat dan tanggap

Ketiga Assurance (jaminan), meliputi kemampuan karyawan atas pengetahuan terhadap produk secara cepat, kualitas keramah-tamahan, perhatian dan kesopanan dalam memberi pelayanan, keterampilan dalam memberikan informasi, kemampuan dalam memberikan keamanan didalam memanfaatkan jasa yang ditawarkan, dan kemampuan dalam menanamkan kepercayaan pelanggan terhadap perusahaan. Dengan memberikan pelayanan yang menunjukkan kesopanan dan kelemah-lembutan akan menjadi jaminan rasa aman bagi nasabah dan yang berdampak pada kesuksesan perusahaan layanan jasa.

Keempat Empathy (empati) yaitu perhatian secara individual yang diberikan perusahaan kepada pelanggan. Perhatian yang ditunjukkan melalui hubungan, komunikasi dan memahami terhadap kebutuhan serta keluhan nasabah. Perwujudan dari sikap empati ini akan membuat nasabah merasa kebutuhannya terpuaskan karena dirinya dilayani dengan baik.

Kelima Tangible (bukti langsung), meliputi fasilitas yang kasat mata yang dapat dinikmati langsung oleh nasabah. Dalam konsep Islam pelayanan yang berkenaan dengan fasilitas yang membuat nasabah merasa nyaman memang penting.

Dari kutipan yang diambil dari buku Strategi Terkini Peningkatan Mutu Pelayanan Kesehatanterdiri dari Konsep dan Implementasi. Pelayanan prima dimaknai sebagai pelayanan terbaik dan telah memenuhi standar pelayanan dipandang dari perspektif pengguna atau donor, perspektif proses pelayanan dan perspektif keuangan yang dapat dicapai jika kualitas sumber daya manusianya cukup profesional. Sementara itu, LAN RI mengartikan pelayanan prima sebagai pelayanan yang terbaik dan melebihi, melampaui, serta mengungguli pelayanan yang diberikan pihak lain atau pelayanan sebelumnya2.

Istilah pelayanan prima sendiri merupakan terjemahan dari excellent service, yang secara harfiah berarti pelayanan yang sangat baik atau pelayanan yang terbaik. Yang menjadi permasalahan adalah bagaimana maksud pelayanan yang sangat baik atau yang terbaik dalam konteks pelayanan kesehatan atau rumah sakit.

Departemen kesehatan telah memberikan pengertian pelayanan prima. Pelayanan prima adalah pelayanan kepada pasien berdasarkan standar mutu untuk memenuhi 
kebutuhan dan keinginan pasien sehingga pasien dapat memperoleh kepuasan yang akhirnya dapat meningkatkan kepercayaannya kepada rumah sakit.

Dalam usaha untuk mencapai usaha Indonesia sehat 2010, Departemen Kesehatan menjelaskan bahwa pelayanan prima seharusnya meliputi aspek-aspek berikut:

1. Kemudahan akses informasi (aspek kepuasan pengguna), pelaksanaan peraturan secara tepat, konsisten, dan konsekuen (aspek proses pelayanan).

2. Pelaksanaan hak dan kewajiban pemberi dan penerima pelayanan (aspek SDM dan kepuasan pelanggan).

3. Penanganan dan pendokumentasian kegiatan pelayanan dilakukan oleh tenaga yang berwenang/ kompeten (aspek proses dan SDM).

4. Penciptaan pola pelayanan yang sesuai dengan sifat dan jenisnya sebagai efisiensi dan efektivitas (aspek SDM, dan proses pelayanan).

5. Penetapan tarif sesuai dengan kemampuan masyarakat dengan mekanisme pungutan yang transparan serta adanya pengendalian dan pengawasan yang cermat (aspek finansial dan kepuasan pelanggan).

6. Tidak ada pembedaan dalam memberikan pelayanan serta pemerataan distribusi cakupan (aspek kepuasan pelanggan).

7. Kebersihan fasilitas pelayanan dan lingkungan (aspek proses pelayanan).

8. Sikap ramah dan sopan petugas serta meningkatkan kinerja secara kualitatif dan kuantitatif dengan kapasitas optimal (aspek kepuasan pelanggan dan aspek SDM).

Ada dilema dalam upaya untuk mewujudkan mutu dalam layanan kesehatan. Pada satu pihak mutu juga diartikan sejauh mana layanan kesehatan yang diberikan sesuai dengan standard operating procedure (SOP) atau prosedur tetap medis. Ketika SOP tersebut dilaksanakan seperti misalnya di beberapa rumah sakit pendidikan milik pemerintah, dianggap oleh pasien terlalu lama dan berbelitbelit. Dari pihak lainnya, menurut kacamata pasien, justru rumah sakit pendidikan milik pemerintah dianggap kurang bermutu dibanding rumah sakit swasta yang dapat lebih cepat karena prosedur yang diterapkan lebih fleksibel1 Ada dilema dalam upaya untuk mewujudkan mutu dalam layanan kesehatan. Pada satu pihak mutu juga diartikan sejauh mana layanan kesehatan yang diberikan sesuai dengan standard operating procedure (SOP) atau prosedur tetap medis. Ketika SOP tersebut dilaksanakan seperti misalnya di beberapa rumah sakit pendidikan milik pemerintah, dianggap oleh pasien terlalu lama dan berbelitbelit. Dari pihak lainnya, menurut kacamata pasien, justru rumah sakit pendidikan milik pemerintah dianggap kurang bermutu dibanding rumah sakit swasta yang dapat lebih cepat karena prosedur yang diterapkan lebih fleksibel.

Dalam proses pelayanan kesehatan akan terjadi variasi pelaksanaan kegiatan dari waktu ke waktu yang akan menghasilkan luaran yang bervariasi juga. Salah satu upaya untuk 
mengurangi variasi proses adalah dengan melakukan standardisasi. Proses standardisasi meliputi penyusunan, penerapan, monitoring, pengendalian, serta evaluasi dan revisi standar (PP 102/2000)3-6. Keberadaan standar dalam pelayanan kesehatan akan memberikan manfaat, antara lain mengurangi variasi proses, merupakan persyaratan profesi, dan dasar untuk mengukur mutu. Ditetapkannya standar juga akan menjamin keselamatan pasien dan petugas penyedia pelayanan kesehatan. Dikuranginya variasi dalam pelayanan akan meningkatkan konsistensi pelayanan kesehatan, mengurangi morbiditas dan mortalitas pasien, meningkatkan efisiensi dalam pelayanan, dan memudahkan petugas dalam pelayanan.

Menurut Ariya Maman dan Suryono Budi Santoso menemukan bahwa:

"Pelayanan menunjukkan hubungan positif dengan minat nasabah, menabung, dimana hasilnya menunjukkan bahwa semakin baik tanggapan yang disediakan akan disukai nasabah maka semakin tinggi keinginan mereka untuk menabung pada bank tersebut.”

Tantangan terbesar terutama muncul dalam mengintergrasikan berbagai upaya improvement atau perbaikan/perubahan. Di Indonesia ini dapat meliputi: Perencanaan dari Kementerian Kesehatan (misalnya dalam bentuk Kerangka Kerja Nasional untuk Peningkatan Mutu Pelayanan Kesehatan / National Healthcare Quality Framework, yang saat ini belum tersedia); Dorongan atau peer pressure dari organisasi profesi (seperti pada saat ini IDAI dan POGI sedang menyusun rencana untuk melakukan Audit Medik Nasional, dimana hasil audit dapat menjadi salah satu bentuk peer pressure); Perubahan manajemen (misalnya perubahan pengelolaan komplain pasien/masyarakat yang saat ini sedang dikembangkan oleh para pemimpin RS yang bergabung dalam PERSI); Pelatihan berkelanjutan (seperti yang saat ini dilakukan oleh berbagai intitusi pendidikan/pelatihan dan perguran tinggi); Memberdayakan konsumen (seperti yang selama ini dilakukan oleh Yayasan Lembaga Konsumen Indonesia misalnya).

Lingkungan merupakan faktor terpenting penunjang keberhasilan perusahaan dalam bersaing. Berbagai kegagalan dalam bisnis diisebabkan oleh kegagalan memahami secara benar lingkungan persaingan. Untuk menentukan tujuan, (Scott) menyatakan bahwa sasaran dan strategi-strategi yang diambil perusahaan harus melakukan analisis mendalam serta menyeluruh mengenai lingkungan tempat perusahaan berada. Lingkungan terdiri atas lingkungan eksternal dan lingkungan internal. Alat yang dipakai untuk menyusun faktorfaktor strategis perusahaan adalah matriks SWOT yaitu Strengths-Opportunities-WeaknesseThreats. Matriks ini menggambarkan secara jelas bagaimana peluang dan ancaman eksternal yang dihadapai perusahaan dapat disesuaikan dengan kekuatan dan kelemahan yang dimiliki internal (Fahmi, 2014).

\section{METODE PENELITIAN}


Penelitian ini berada di Jl.Dr.FL Tobing No 2 Rumah Sakit Umum Daerah Padangsidimpuan Kota padangsidimpuan. Adapun jenis penelitian ini adalah penelitian kualitatif. Penelitian kualitatif adalah penelitian yang berlandaskan pada filsafat post positivism, digunakan meneliti pada kondisi objek yang alamiyah, dimana peneliti adalah instrument kunci, pengambilan sumber data dilakukan secara purposive dan snowball, teknik pengumpulan data dengan triangulasi (gabungan), analisis data bersifat induktif/kualitatif dan hasil penelitian lebih menekankan makna daripada generalisasi (Lestari dan Yudhanegara, 2015).

Adapun unit analisis yang dilakukan dalam penelitian ini yaitu manajer puncak, divisidivisi dan keseluruhan objek penelitian yang dapat dijangkau. Data primer adalah data yang diperoleh secara langsung dari subjek penelitian sebagai informasi. Data sekunder adalah data yang bukan diusahakan sendiri pengumpulannya oleh peneliti misalnya dari biro statistik, majalah, koran dan publikasi lainnya. Data sekunder merupakan data yang diperoleh secara tidak langsung dari subjek penelitian sebagai informasi. Untuk penelitian ini data sekunder diperoleh dari buku-buku yang mendukung.

Data yang digunakan dalam penelitian ini yaitu data primer, sedangkan instrument atau alat penelitian yang digunakan adalah peneliti sendiri dan kemungkinan akan dikembangkan instrument penelitian sederhana, yang diharapkan dapat melengkapi data dan membandingkan data yang telah dikemukakan melalui obsevasi atau melaui wawancara.

Teknik pengumpulan data merupakan langkah yang paling utama dalam penelitian, karena tujuan utama dalam peneltian adalah mendapatkan data. Tanpa mengetahui teknik pengumpulan data, maka peneliti tidak akan mendapatkan data yang memenuhi standar data yang ditetapkan (Sugiyono, 2013). Dalam penelitian kualitatif pengumpulan data yang dilakukan pada natural setting dan teknik pengumpulan data lebih banyak pada observasi peranserta dan wawancara mendalam.

Adapun analisis data yang diperlukan dalam penelitian ini adalah menganalis bagaimana kondisi internal (kekuatan dan kelemahan) di Rumah Sakit Umum padangsidimpuan. Kemudian peneliti Menganalisis bagaimana kondisi eksternal (peluang dan ancaman) rumah sakit ini. Kemudian peneliti menyusun matriks SWOT dan menganalisis SWOT yaitu bagaimana strategi pihak rumah sakit mengembangkan pelayanan.

\section{HASIL DAN PEMBAHASAN}

Berdasarkan surat Keputusan Menteri Kesehatan RI tanggal 22 Februari 1979 No: 51/MENKES/SK/11/1979. Rumah sakit Umum Padangsidimpuan ditetapkan sebagai rumah 
sakit kelas $\mathrm{C}$ dan merupakan salah satu instansi pemerintah berstatus negeri, rumah sakit ini banyak menyediakan layanan diantaranya pelayanan administrasi dan manajemen, pelayanan-pelayan medis dan pelayanan-pelayanan penunjang non medis.

Kepuasan pasien merupakan kunci penting meningkatkan quality care dalam pelayanan kesehatan, health care provider perlu menyadari bahwa keuntungan utama sistem pelayanan kesehatan adalah pasien. Pasien yang puas akan selalu nyaman di rumah sakit dalam waktu lama, selalu kembali dan merekomendasikan kepada orang lain. 3 hal ini merupakan bagian indikator pengukuran kepuasan pasien dalam penilaian health care provided, dengan meningkatnya pertumbuhan rumah sakit yang berbanding lurus dengan peningkatan pengetahuan pasien tentang apa yang seharusnya didapatkan, maka pasien membutuhkan rumah sakit yang menyediakan semua yang dibutuhkan.

Tingginya pendapatan rumah sakit dapat meningkatkan kualitas pelayanan dan pasien akan mempertimbangkan untuk terus memanfaatkan rumah sakit tersebut misalnya berdasarkan pengalaman memanfaatkan rumah sakit sebelumnya dan kesalahan pelayanan yang pernah dilakukan.

Sofaer dan Firminger, mengidentifikasi:" 7 kategori penting untuk pasien antara lain: Patien centered care, akses, kesopanan, komunikasi dan informasi, skill, efisiensi dan fasilitas yang memadai." 7 kategori ini perlu ditingkatkan dan dibuat dalam perencanaan, implementasi dan evaluasi untuk mencapai kualitas pelayanan sesuai standar, selain itu perlu meningkatkan komunikasi secara efektif dengan pasien sehingga terbangun hubungan yang harmonis dan leluasa dalam mengidentifikasi masalah dan memperbaiki performance rumah sakit untuk mencapai kualitas pelayanan berbasis kepuasan pasien.

Rumah Sakit Umum Daerah Padangsidimpuan ini dikenal oleh masyarakat tapanuli bagian Selatan akan tetapi terdapat berbagai keluhan dari masyarakat terkat pelayanan yang disediakan diantaranya kurangnya dokter-dokter yang ahli atau spesialis untuk menangani masalah pasien, kurangnya pasokan air bersih, kebersihan lokasi tidak begitu diperhatikan, kurangnya fasilitas yang diberikan rumah sakit sehingga bayak sekali komplain atau keluhan dari pasien atau masyarakat ketika menginap maupun berkunjung kerumah sakit itu. Adapun visi dan misi Rumah Sakit Umum Padangsidimpuan sebagai berikut:

1. Visi

Rumah sakit umum yang diminati oleh masyarakat

2. Misi

Mewujudkan pelayanan kesehatan secara profesional

Mewujudkan pengelolaan rumah sakit umum yang transparan dan akuntabel

3. Tujuan 
Menjadikan rumah sakit rujukan di pantai barat, Terwujudnya peningkatan kualitas, disiplin aparatur, dan pengelolaan administrasi, keuangan yang dapat mendukung peningkatan pelayanan kesehatan .

4. Sasaran
a. Meningkatkan kualitas dan kuantitas aparatur
b. Meningkatkan kualitas dan kuantitas sarana dan prasarana
c. Tercapainya akreditasi rumah sakit
d. Meningkatnya kualitas sarana, prasarana, dan aparatur motivasi kerja
e. Tercapainya pengelolaan administrasi dan keuangan yang akuntabel

5. Tugas Pokok

Melaksanakan upaya kesehatan secara berdaya guna dan berhasil guna dengan mengutamakan upaya penyembuhan dan pemulihan yang dilakukan secara serasi, terpadu dengan upaya pengoabatan dan pencegahan penyakit kepada pasien secara langsung dan dengan melalui rujukan b. Melaksanakan pelayanan yang bermutu sesuai dengan etika dan pelayanan rumah sakit, evaluasi pelaksanaan dan pelaporan

6. Fungsi

a. Menyelenggarakan pelayanan medis

b. Menyelenggarakan pelayanan penunjang medis dan non medis

c. Menyelenggarakan pelayanan rujukan

d. Menyelenggarakan pendidikan dan pelatihan

e. Menyelenggarakan administrasi umum dan keuangan

\section{Analisis lingkungan Internal}

Kekuatan keuangan yang dimiliki perusahaan ini yaitu uang masuk tiap bulannya dati iuran BPJS sehingga akan menambahkan kas rumah sakit dan dapat menggaji pekerja harian diRumah sakit Umum Padangsidimpuan dan satu faktor kelemahan dibidang keuangan ini adalah rendahnya bayaran ruangan inap sehingga para pasien hanya membayar sekitar Rp30.00o per malam. Adapun dari segi manajemen control pasien selalu dikontrol dua kali dalam tiga jam setiap harinya. Akan tetapi bagi pekerja yang dinas dimalam hari kurang begitu memperhatikan keadaan pasien yang menginap di ruangan, Sehingga banyak sekali didengar keluhan dari para pasien.

\section{Analisis Lingkungan Eksternal}

Adapun peluang yang berkaitan dengan pemerintahan yaitu RSUD Padangsidimpuan memiliki dukungan penuh dari pemerintah sehingga tidak ada pihak luar yang ikut campur 
dalam hal mengurusi rumah sakit. Akantetapi ancaman yang didapat pihak rumah sakit tidak dapat menaikkan standar biaya yang sudah ditetapkan karena pasien yang datang rata-rata pasien yang memiliki kartu BPJS, jika ada perubahan harus melalui persetujuan pemerintah.

Adapun dari segi saingan perusahaan, RSUD Padangsidimpuan mempunyai peluang yang sangat baik karena rumah sakit inilah satu-satunya rumah sakit yang berstatus negeri di Kota Padangsidimpuan dan biaya yang diberikan kepada masyarakat relative murah sehingga masyarakat tetap bertahan berobat dan bertahan menerima layanan dari pihak rumah sakit. Akantetapi, munculnya rumah sakit - rumah sakit swasta menjadi ancaman dan membuat RSUD Padangsidimpuan lebih diantisipasi.

\section{Analisis SWOT}

RSUD Padangsidimpuan sangat unggul disbanding rumah sakit lain, karena inilah satu-satunya rumah sakit yang berstatus negeri di Kota Padangsidimpuan. RSUD Padangsidimpuan ini memiliki alat medis yang lengkap dalam melakukan tindakan medis, demikian juga halnya rumah sakit ini menerima surat rujukan dari rumah sakit swasta jika pasien dirumah sakit swasta tidak dapat ditangani.

Disamping kekuatan yang dimiliki rumah sakit ini, akantetapi, ada juga kelemahan yang didapati yaitu bila dibandingkan dengan jumlah rasio pasien, jumlah dokter tidak memadai sehingga penanganan pasien kurang maksimal. Kekurangan lainnya yaitu kebersihan ruangan kurang diperhatikan, kurangnya tingkat keramahan dan kesopanan perawat terhadap pasien maupun keluarga pasien apabila dibandingkan dengan pelayanan di rumah sakit swasta.

Peluang yang dimiliki rumah sakit umum sangat bagus, disebabkan pemerintah memberikan perhatian penuh untuk memajukan dan mengembangkan rumah sakit umum. Adapun yang menjadi ancaman bagi instansi pemerintah ini yaitu, masyarakat lebih merasa puas dengan pelayanan yang diberikan oleh pihak rumah sakit swasta dibandingkan dengan rumah sakit umum negeri. karena, pihak rumah sakit swasta lebih cepat menanggapi keluhan yang dialami oleh pasien mereka.

\section{Matriks SWOT}

Berdasarkan hasil dari observasi faktor internal dan faktor eksternal yang dilakukan maka perlu dijelaskan isi dari matriks SWOT sebagai berikut:

a. Strategi SO

Adanya dorongan dari pemerintah untuk pembangunan gedung baru dan melengkapi fasilitas-fasilitas medis yang belum pernah ada dalam menangani masalah pasien supaya kekurangan yang ada tertutupi.

b. Strategi WO 
Bantuan dari pemerintah dan manajer puncak sangat membantu membuat team khusus dalam menangani masalah kebersihan yang ada.

c. Strategi ST

RSUD Padangsidimpuan masih menjadi minat sebagian besar masyarakat, sebab rumah sakit ini satu-satunya rumah sakit yang berada dibawah kaki tangan pemerintah di Kota Padangsidimpuan.

d. Strategi WT

Peningkatan pelayanan yang akan memuaskan pasien dan keluarga. Janji dari perawat dan dokter harus selalu melayani pasien dengan setulus hati, jika pelayanan yang diberikan kepada pasien sangat baik maka kekurangan akan tertutupi.

\section{KESIMPULAN}

Berdasarkan hasil analisis SWOT yang digambarkan bahwa Rumah Sakit Umum Padangsidimpuan memaksimalkan strategi S-O, W-O, S-T dan W-T.Rumah Sakit Umum Padangsidimpuan berusaha memanfaatkan kekuatan dan peluang serta mengatasi kelemahan dan ancaman.Adapun kekuatan yang diperoleh meliputi: satu-satunya rumah sakit negeri di Kota padangsidimpuan, memiliki alat medis yang lengkap dan pihak rumah sakit menerima surat rujukan dari rumah sakit lainnya.

Adapun kelemahan yang didapatkan yaitu: sedikitnya jumlah dokter dan kurang diperhatikannya kebersihan dirumah sakit ini.Adapun peluang yang diperoleh yaitu adanya partisipasi dari pemerintah Kota Padangsidimpuan dalam peningkatan pembangunan gedung serta pembangunan fisik lainnya. Adapun yang menjadi ancaman bagi rumah sakit ini yaitu: Adanya rumah sakit -rumah sakit swasta sebgai saingan dan pelayanan di ruamah sakit swasta lebih baik dibandingkan di Rumah Sakit Umum padangsidimpuan.

Peneliti memberikan saran sebagai berikut:

1. Manajer pusat harus lebih fokus dengan tim kebersihan di lingkungan RSUD, karena kebersihan merupakan hal yang sangat penting dalam kenyamanan di RSUD Padangsidimpuan.

2. Perlu ditingkatkan jumlah dokter khususnya dokter spesialis karena dengan bertambahnya jumlah dokter maka pelayan berkualitas

3. Fasilitas medis, maupun non medis yang ada hubungannya langsung dengan kenyamanan perlu ditingkatkan

4. Di dalam Islam, melayani pasien harus cepat dan tepat dan tidak pandang bulu. 


\section{DAFTAR PUSTAKA}

David, R, Fred. 2009. Strategis Managemen, “ Manajemen Strategis” terj: Sunardi. Jakarta: Salemba Empat.

Fahmi, Irham. 2014. Manajemen Strategi Teori dan Konsep. Bandung: Alpabeta

Hasan, Ali. 2010. Marketing Bank Syariah. Bogor: Ghalia Indonesia

Henri, Desri. 2010. "Analisis Penegembangan Rawat Inap Rumah Sakit Umum Padang”. Skripsi,UNP Sumatera Barat.

Jurnal Kesehatan Masyarakat, Maret - September 2008, II (2) Universitas Andalas.

Lestari, Eka, Karunia dan Yudhanegara, Ridwan, Muhammad. Penelitian Pendidikan Matematika. Bandung: Refika Aditama.

Sai'd, Gumbira. 2003. Manajemen Strategis Perspektif Syariah, Jakarta Selatan, Khoirul Bayaan.

Scott M Cutlit, dkk. Effective Public Relation terj: Tri Wibowo. Jakarta: Kencana Prenada Media Group.

Sugiyono. 2013. Metode Penelitian Pendidikan. Bandung: Alfabeta.

Sule, Tisnawati, Ernia dan Saefullah, Kurniawan. 2000. Pengantar Manajemen. Jakarta: Kencana Prenada Media Group.

Usman, Halim, Abdul. 2015. Manajemen Strategi Syariah. Jakarta Timur: Zikrul Hakim.

Wulan, Retno, Riris dan Mosam, Muhammad. Peningkatan Kualitas Pelayanan Publik dalam Rangka Reformasi Birokrasi di kantor pertanahan Kota Semarang, Universitas Diponegoro: Skripsi. 